\title{
Residual value of inorganic fertilizer and farmyard manure for crop yields and soil fertility after long-term use on a loam soil in Norway
}

\section{Hugh Riley}

NIBIO, Arable Crops Division, Apelsvoll, Nylinna 226, N-2849 Kapp, Norway, hugh.riley@bioforsk.no

Use of mineral NPK fertilizer and farmyard manure has been compared since 1922 in a mixed arable crop rotation on loam soil. During the period 1982- 2003, cattle manure at rates of 20-60 Mg ha-1 $\mathrm{yr}^{-1}$ gave yields that were $80-90 \%$ of those obtained using mineral fertilizer at $100 \mathrm{~kg} \mathrm{~N}: 25 \mathrm{~kg} \mathrm{P}: 120 \mathrm{~kg} \mathrm{~K} \mathrm{ha}^{-1} \mathrm{y}^{-1}$. Approximate balance between nutrient supply and removal was achieved at the lowest manure rate, but higher manure rates resulted in large surpluses of all three nutrients. In order to study residual effects of these surpluses, no manure was applied from 2004 to 2007 and mineral fertilizer was withheld from some NPK plots. Residual effects were evaluated both in relation to plots without any nutrient supply since 1922 and plots that still received $100 \mathrm{~kg} \mathrm{~N}, 25 \mathrm{~kg} \mathrm{P}$ and $120 \mathrm{~kg} \mathrm{~K} \mathrm{ha}^{-1}$ each year. No residual effect of mineral fertilizer was found, but the previous use of manure gave large residual effects on both yield and nutrient uptake, with yields remaining at around $85 \%$ of those obtained with mineral fertilizer. Soil analyses in 2007 showed effects of both mineral fertilizer and manure on available nutrients, $\mathrm{pH}$ and soil organic matter. Applications of manure and fertilizer were resumed in 2008 on most plots, but not in those with the highest manure rate, where residual effects were measured until 2013. This treatment continued to show large residual responses in both yields and nutrient uptakes throughout the period. 